infections. The association between genitourinary symptoms and vaginal anaerobic infection warrants further study. Meanwhile there is little to indicate that, with the possible exception of Corynebacterium vaginale, ${ }^{24}{ }^{25}$ other bacteria have any pathogenic role in the vagina of the great majority of young women.

This study was financed by a grant from the Scottish Home and Health Department. We thank Mrs Grace Grant for conducting the interviews, and the doctors at the Edinburgh Family Planning Centre who participated in the study-namely, Dr Agnes Begg, Dr Isabel Herbert, Dr Kathleen G Macleod, Dr Marion More, Dr Anne L Munro, Dr Rhoda Scott, and Dr Elizabeth Sudlow. We also thank the nursing staff, particularly Mrs Mary Rankin and Mrs Margaret Foxwell; and Mr D J Annat and Miss B Fraser for technical help.

Details of culture media, isolation procedures, and definitions used may be obtained from: Dr M J Goldacre, Department of Social Medicine, University of Oxford, 8 Keble Road, Oxford OX1 3QN.

\section{References}

${ }^{1}$ Hurley, R, and Morris, E D, fournal of Obstetrics and Gynaecology of the British Commonwealth, 1964, 71, 692.

${ }^{2}$ Gardner, H L, Dampeer, T K, and Dukes, C D, American fournol of Obstetrics and Gynecology, 1957, 73, 1080.

${ }^{3}$ Raphael, M, and Levy, B, Fournal of the Royal College of General Practitioners, 1977, 27, 349 .

${ }^{4}$ Oriel, J D, et al, British Medical fournal, 1972, 4, 761.
${ }^{5}$ Rohatiner, J J, and Grimble, A, Fournal of Obstetrics and Gynaecology of the British Commonwealth, 1970, 77, 1013.

${ }^{6} \mathrm{Ohm}, \mathrm{M} \mathrm{J}$, and Galask, R P, American fournal of Obstetrics and Gynecology, 1975, 122, 683.

Neary, M P, et al, Lancet, 1973, 2, 1291.

${ }^{8}$ De Louvois, J, Hurley, R, and Stanley, V C, fournal of Clinical Pathology, $1975,28,731$

Slotnik, I J, Stelluto, M, and Prystowski, H, American fournal of Obstetrics and Gynecology, 1963, 85, 519 .

${ }^{10}$ Morris, C A, and Morris, D F, fournal of Clinical Pathology, 1967, 20, 636

${ }^{11}$ Corbishley, C M, fournal of Clinical Pathology, 1977, 30, 745.

${ }^{12}$ Tashjian, J H, Coulam, C B, and Washington, J A, Mayo Clinic Proceedings, 1976, 51, 557.

13 Goldacre, M J, et al, British Medical fournal, 1978, 1, 748.

14 Taschdjian, C L, Birchall, J J, and Kozinn, P J, American fournal of Diseases of Children, 1960, 99, 212.

${ }^{15}$ Lodder, J, The Yeasts-a Taxonomic Study. Amsterdam, North Holland Publishing Company, 1970.

${ }^{16}$ Watt, B, and Jack, E P, fournal of Medical Microbiology, 1977, 10, 461

17 Catterall, R D, Lancet, 1966, 2, 830.

${ }^{18}$ Walsh, H, Hildebrandt, R J, and Prystowski, H, American fournal of Obstetrics and Gynecology, 1968, 101, 991.

${ }^{19}$ Morris, C A, Fournal of Clinical Pathology, 1969, 22, 489.

20 Loudon, N, unpublished observations.

${ }^{21}$ Thadepalli, H, Gorbach, S L, and Keith, L, American fournal of Obstetrics and Gynecology, 1973, 117, 1034.

${ }^{22}$ Targum, S D, and Wright, N H, American fournal of Epidemiology, 1974 100,262

${ }^{23}$ Vessey, M P, et al, Fournal of Biosocial Science, 1976, 8, 373.

${ }^{24}$ Pheifer, T A, et al, New England fournal of Medicine, 1978, 298, 1429.

${ }^{25}$ Lancet, 1978, 2, 459.

(Accepted 18 April 1979)

\title{
Vagotomy and pyloric dilatation in chronic duodenal ulceration
}

\author{
J D THOMSON, J B W GALLOWAY
}

British Medical fournal, 1979, 1, 1453-1455

\begin{abstract}
A total of 101 patients suffering from duodenal ulcer underwent truncal vagotomy (TV) combined with pyloric dilatation (PD). They were followed up over six years, and the results were found to compare favourably with those in patients who underwent alternative surgical measures. Before any revisionary surgery 79 patients were classified as Visick grades I plus II. The incidence of recurrent ulceration was $4 \%$. Side effects were noticeably less common than in patients in whom a drainage procedure had been performed, and overall results were compared with those reported for groups of patients treated by proximal gastric vagotomy.

The combination of $T V$ and $P D$ is commended on account of its simplicity, safety, and effectiveness at a time when medical treatment for duodenal ulcer is becoming more specific and increasingly effective.
\end{abstract}

\section{Introduction}

Although the advent of $\mathrm{H}_{2}$-receptor antagonists has to some extent altered the attitude of many clinicians to the management of

Ballochmyle Hospital, Mauchline, Ayrshire KA5 6LQ

J D THOMSON, MB, FRCS, consultant surgeon

J B W GALLOWAY, MA, FRCS, medical assistant in surgery duodenal ulceration, such advances in medical treatment have emphasised the need for a safe, simple, and effective elective surgical alternative should conservative management fail. Since Dragstedt ${ }^{1}$ established truncal vagotomy (TV) as an acceptable method of treatment workers have realised that an appreciable number of patients do not require a concomitant drainage procedure to overcome problems related to gastric stasis, and that such additional procedures as gastroenterostomy or pyloroplasty may give rise to certain undesirable sequelae. ${ }^{2}$ More recently interest has centred on establishing a technique whereby the stomach can be adequately vagotomised without giving rise to difficulties associated with gastric emptying. This work culminated in the introduction into clinical practice of the concept of proximal gastric vagotomy (PGV) in 1969 by Johnston and Wilkinson. ${ }^{3}$

A vast amount of work, both clinical and experimental, has been done on the physiological effects of vagal section. ${ }^{4}$ In so far as gastric motility is concerned most workers seem generally to agree that any stasis that results from vagotomy is most probably variable in degree and temporary in nature. ${ }^{5}$ There would seem, therefore, to be little logic in rendering the stomach permanently incontinent as a matter of routine by performing either of the usual drainage procedures in order to overcome an essentially transient problem. The function of the gastric antrum and pylorus should be retained whenever possible. In cases in which the gastric outlet is found at laparotomy not to be unduly scarred or fibrosed we have overcome the transient problems of postvagotomy stasis by gradually stretching the smooth-muscle fibres of the pyloric canal and thus facilitating gastric emptying. We here report the results of TV and pyloric 
dilatation (PD) in a series of 101 patients followed up over six years.

\section{Patients and methods}

All patients who underwent TV and PD were included in the study with the exception of two who were lost to follow-up and one who died of coronary disease three years after operation, leaving a total of 101 for review. They presented with acceptable symptoms of duodenal ulceration supported by radiological confirmation, and in most cases positive evidence was obtained either on endoscopy or at laparotomy. Some patients had other serious gastrointestinal conditions. Studies of gastric emptying were carried out in some patients using technetium- $99 \mathrm{~m}$, and fibreoptic recordings were made in some others from five days to five years after operation with particular reference to antral and pyloric function. ${ }^{6}$

No particular surgical expertise is required to carry out the procedure. A TV is completed in the usual manner and a stab gastrotomy made proximal to the antrum to permit the introduction of a Tubbs dilator, which is then advanced until the parallel limbs lie in the pyloric canal. Gradual dilatation is carried out up to a maximum of $4 \mathrm{~cm}$ so as to temporarily widen the canal without producing any morphological change in the musculature that might interfere with motility or the pace-setter potential of the gastric antrum and proximal duodenum. Preliminary experiments were carried out on rabbits, ${ }^{i}$ \& and tissue removed from the pyloric canal at varying intervals was submitted to examination by light and electron microscopy. Similar studies were made in some patients. These investigations indicated that the degree of dilatation did not cause any change of an organic nature in the region of the gastric outlet.

\section{Results}

The operative mortality was nil, and all were well when discharged from hospital. Return to normal feeding while in the ward was considered to be earlier in these patients than in those in whom a drainage procedure had been performed. The follow-up was conducted by interview at regular intervals and the patients accorded a Visick category as shown in table I.

TABLE I-Overall grading of results in 101 patients after truncal vagotomy and pyloric dilatation

$\left.\begin{array}{llc}\hline & \text { Grade } & \begin{array}{c}\text { No of } \\ \text { patients }\end{array} \\ \hline \text { I } & \text { No symptoms } & 67 \\ \text { II } & \text { Symptoms not requiring treatment } & 12\} 78 \% \\ \text { III } & \text { Symptoms responding to treatment } & 12 \\ \text { IV } & \text { Symptoms failing to respond to treatment } & 10\end{array}\right\} 22 \%$

Most patients in whom the result was unsatisfactory and who fell into Visick grades III and IV suffered to varying degrees from epigastric discomfort, nausea, and vomiting. Four were identified as having a recurrent duodenal ulcer and underwent revisional surgery. One patient with troublesome vomiting had a fibrotic pyloric canal cracked at dilatation, and the defect was oversewn "in axis," with subsequent development of an organic obstruction of the gastric outlet that required drainage. Such a patient would not now be considered to be suitable for dilatation. Two patients with troublesome vomiting presented with postvagotomy gastric stasis. In one a barium $x$-ray film showed a hold-up at the gastric outlet but this was not confirmed on fibroscopy and there was evidence of gastric stasis. In the other case there was again clinical and endoscopic evidence of stasis but this was later complicated by recurring acute calculous cholecystitis. Both these patients underwent revisional surgery, the first having a gastrojejunostomy and the second a gastrojejunostomy and later cholecystectomy. In both the symptoms subsequently improved. One patient with an appreciable hiatal defect suffered sufficiently from reflux to warrant fundoplication (table II).

Twelve other patients complained of occasional epigastric discomfort accompanied at times by nausea and vomiting. Three of these showed positive reactions to a Hollander test but had no evidence of recurrent ulceration. All received appropriate medical treatment and none was considered to be a candidate for revisional surgery.
TABLE II-Details of revisional surgery

\begin{tabular}{|c|c|c|c|}
\hline $\begin{array}{l}\text { Case } \\
\text { No }\end{array}$ & $\begin{array}{l}\text { Reason for revisional } \\
\text { surgery }\end{array}$ & $\begin{array}{c}\text { Time since } \\
\text { primary } \\
\text { operation (years) }\end{array}$ & Revisional procedure \\
\hline 1 & Recurrent ulcer & 1 & Gastroenterostomy \\
\hline $\begin{array}{l}2 \\
3\end{array}$ & " & $\frac{1}{2}$ & $\begin{array}{l}\text { Completion of vagotomy } \\
\text { plus antrectomy }\end{array}$ \\
\hline $\begin{array}{l}4 \\
5\end{array}$ & $\begin{array}{c}" \\
\text { Gastric-outlet fibrosis }\end{array}$ & $\begin{array}{l}5 \\
3\end{array}$ & $\begin{array}{l}\text { Gastroenterostomy } \\
\text { Completion of vagotomy } \\
\text { plus gastroenterostomy }\end{array}$ \\
\hline $\begin{array}{l}6 \\
7 \\
8\end{array}$ & $\begin{array}{l}\text { Calculous cholecystitis } \\
\text { Gastric stasis } \\
\text { Gastric stasis with } \\
\text { cholecystitis }\end{array}$ & $\begin{array}{l}3 \\
2 \\
3\end{array}$ & $\begin{array}{l}\text { Cholecystectomy } \\
\text { Gastroenterostomy } \\
\text { Gastroenterostomy plus } \\
\text { cholecystectomy }\end{array}$ \\
\hline 9 & Reflux oesophagitis & 5 & Fundoplication \\
\hline
\end{tabular}

TABLE III-Visick grading in all 101 patients after revisional surgery and appropriate medical treatment

\begin{tabular}{lcccccc}
\hline $\begin{array}{l}\text { Visick grade } \\
\text { No of patients }\end{array}$ & I & II & III & IV & I + II & III + IV \\
& 69 & 17 & 12 & 3 & $86\left(85^{\circ}{ }^{\prime \prime}\right)$ & $15\left(15^{\prime \prime}\right)$ \\
\hline
\end{tabular}

Also included in this group, and emphasising the need for careful selection, were two patients with symptomatic hiatal hernias, one with cirrhosis of the liver and one incapacitated with hypertension.

Diarrhoea as a sequel of postvagotomy surgery appears to require some form of definition as it is interpreted in various ways by clinicians. Many patients experience some alteration in bowel habit after TV, and a few are pleased with this. Such changes also occur after various operations on the stomach with or without any form of vagotomy. ${ }^{9}$ Vagal denervation of the stomach alters rates of gastric emptying differentially, fluids or semi-fluids passing more rapidly into the intestine than solids, and this probably accounts for some of the intestinal hurry that may occur in the early postoperative phase. This form of diarrhoea tends to be of limited duration, and in most cases the bowel rhythm reverts to normal in about two to three months postoperatively. In the present series 14 patients came within this category, having diarrhoea of a mild or moderate degree for a limited period. Three of these patients continued to have a "trigger bowel" - that is, an occasional loose, solitary but urgent stool, most often in response to an identifiable item of diet (for example, cucumber) or drink (for example, beer). One of the patients who developed postvagotomy stasis had troublesome and persistent diarrhoea, but this settled considerably after a gastroenterostomy had been carried out at revisional surgery.

Table III shows the Visick grading after revisional surgery and appropriate medical treatment in all patients.

\section{Discussion}

Ever since vagotomy became the operation of choice in the elective management of chronic duodenal ulceration, clinicians have been aware of the desirability of retaining the function of the gastric antrum and pyloric canal whenever possible. In a review of his earlier cases in 1948 Dragstedt $^{1}$ reported that most of the patients had done well after TV alone, but he reluctantly advised a concomitant gastroenterostomy, recognising that although it produced certain undesirable features the overall results were probably better. More recently, Burge ${ }^{10}$ in 1969 recorded good results in a series of 120 patients who were treated by selective vagotomy without drainage. He indicated, probably correctly, that in the absence of stenosis of the pyloric canal the stomach empties better without drainage than it does after any of the so-called pyloroplasty procedures. Kirk, ${ }^{11}$ reviewing a series of patients in whom he had performed various vagotomy procedures without drainage ( $\mathrm{TV}$, selective vagotomy, PGV), recorded satisfactory results in $79 \%$. He concluded that, until it is possible to predict those who will develop retention, patients should be spared high-risk operations and those that may produce undesirable and possibly irrevocable sequelae.

In our study we encountered problems related to gastric stasis in two patients, of whom one had the complicating features of cholecystitis. There is no evidence clinically or 
microscopically that the degree of dilatation of the pyloric canal used $(4 \mathrm{~cm})$ causes any morphological change in the mucosa or the musculature of the wall. On the other hand, clinical, radiological, and endoscopic evidence shows that the intricate mechanism of the antropyloroduodenal channel is not destroyed, as, for example, in pyloroplasty. Bile reflux was not seen clinically, and no patient developed a postoperative gastric ulcer. We believe that patients return to normal feeding earlier and that the incidence of undesirable sequelae is lower after TV and PD compared with patients in whom one of the conventional drainage procedures have been performed. Further study will be required before any real comparison can be made with the results after PGV.

Goligher, ${ }^{12}$ reporting on a series of 117 patients who underwent PGV and were followed up for five to eight years, recorded a similar overall result in terms of Visick gradingnamely, $75^{\circ}{ }^{\circ}$ in categories I plus II. As compared with vagotomy and drainage he concluded that PGV was followed by less dumping and diarrhoea but did not offer appreciably better overall results. Mackey et al, ${ }^{13}$ reporting on a series of 115 patients who had been treated by PGV and followed up for one to five years in a district general hospital, recorded a satisfactory result in $91 \%$. Their incidence of recurrent ulceration was $5 \cdot 1^{\circ}{ }_{0}$ after an average interval of two years and that of new gastric ulceration $2.5^{\circ} \%$ after an average of four years.

PGV is a technically exacting procedure attended by anxieties related to the vascularity of the lesser curvature of the stomach. ${ }^{1+15}$ By contrast, TV and PD is both safe and economic in terms of time and manpower and complies with Dragstedt's view $^{16}$ that "the operation for elective duodenal ulcer surgery must be safe in the hands of the average surgeon using a technique that is acceptably effective."

We are indebted to our surgical and nursing colleagues who have contributed to this study and to Dr D McEwan Jenkinson and Dr G E Thomson, of the Hannah Research Institute, for their collaboration in experimental work. We thank Mrs Helen Graham for secretarial support, and acknowledge a grant from the Ayrshire and Arran Health Board.

\section{References}

${ }^{1}$ Dragstedt, L R, and Camp, E H, Gastroenterology, 1948, 11, 460

${ }^{2}$ McKelvey, S T D, British fournal of Surgery, 1970, 57, 741.

${ }^{3}$ Johnston, D, and Wilkinson, A R, British fournal of Surgery, 1970, 57, 289.

4 Baron, J H, and Spencer, J, Surgical Clinics of North America, 1976, 56, 1297.

${ }^{5}$ Green, R, Spencer, A, and Kennedy, T, British fournal of Surgery, 1978, 65, 161.

'MacKenzie, I, personal communication.

7 Thomson, G, personal communication.

${ }^{8}$ Jenkinson, D, and Stewart, J, personal communication.

9 Tanner, N C, Surgical Clinics of North America, 1976, 56, 1349.

10 Burge, H, British Medical fournal, 1971, 1, 172

${ }^{11}$ Kirk, R M, Proceedings of the Royal Society of Medicine, 1975, 68, 179.

${ }^{12}$ Goligher, J C, et al, British fournal of Surgery, 1978, 65, 145.

${ }_{13}$ Mackey, D A, et al, British fournal of Surgery, 1979, 66, 39.

${ }_{14}$ Moore, F P, et al, British Medical fournal, 1975, 4, 328.

${ }_{15}$ Heffernan, S J, British Medical fournal, 1976, 1, 398.

${ }^{16}$ Dragstedt, L R, in Vagotomy on Trial, ed A G Cox and J AlexanderWilliams. London, Heinemann, 1973.

(Accepted 20 April 1979)

\title{
Proximal gastric vagotomy, fundoplication, and lesser-curve necrosis
}

\author{
T KENNEDY, P MAGILL, G W JOHNSTON, T G PARKS
}

British Medical fournal, 1979, 1, 1455-1456

\section{Summary and conclusions}

Out of 400 patients who underwent proximal gastric vagotomy (PGV), three developed lesser-curve necrosis (LCN) leading to perforation within the first seven days. In each case diagnosis was delayed but the patient survived after a second operation. In each an associated Nissen fundoplication had been carried out; we used the combined operation in only 33 patients. Delayed LCN occurred in a patient who had undergone splenectomy at the time of the PGV and in a fifth patient treated elsewhere who had also undergone fundoplication.

These findings indicate that early postoperative gastric distension with gas, not readily voided after fundoplication, may aggravate local vascular factors and predispose to LCN. We suggest that PGV combined with fundoplication may be dangerous.

The Royal Victoria Hospital, Belfast BT12 6LA

$T$ KENNEDY, MS, FRCS, consultant surgeon

P MAGILL, MB, FRCS, senior surgical registrar

G W JOHNSTON, MCH, FRCs, consultant surgeon

$T$ G PARKS, MCH, FRCS, reader in surgery

\section{Introduction}

Since 1974 sporadic cases of lesser-curve necrosis (LCN) after proximal gastric vagotomy (PGV) have been reported. ${ }^{1-5}$ Necrosis and perforation were fatal in three of the first seven reported cases. The rarity of LCN is shown by Johnston's world-wide survey ${ }^{6}$ of 5539 PGVs, in which five deaths occurred from this cause. Though rare, LCN is possibly the most important single cause of death after PGV, which is otherwise a safe operation, with a mortality of $0.2 \%{ }_{0}{ }^{6} \mathrm{~A}$ variant of the condition, in which a lesser-curve ulcer appears within a week or two of PGV, has also been described. ${ }^{7-9}$

The precise cause of LCN is not known. Uraemia, excessive use of diathermy, and inexperience of the surgeon have all been blamed. We have recently encountered three instances each associated with Nissen's fundoplication.

\section{Case reports}

Case 1-A man aged 37 with duodenal ulcer and hiatus hernia underwent a straightforward PGV and fundoplication. A few branches of the right gastroepiploic vessels were ligated. The lesser curve was not reperitonealised. On the fifth day sudden pain occurred in the left chest and shoulder and pulmonary embolus was suspected. On the sixth day there were signs of peritonitis, and at reoperation a necrotic area was found just below the fundoplication. This was sutured. He made an uninterrupted recovery and remained well one year later.

Case 2-A man aged 42 with duodenal ulcer and hiatus hernia underwent PGV and fundoplication, and the lesser curve was 